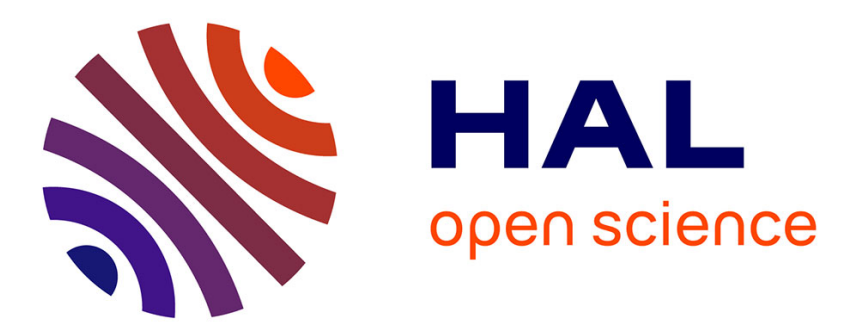

\title{
Effects of fish stocking and fishing pressure on fish community structures in French lakes
}

Léa Daupagne, Marlène Rolan-meynard, Maxime Logez, Christine Argillier

\section{To cite this version:}

Léa Daupagne, Marlène Rolan-meynard, Maxime Logez, Christine Argillier. Effects of fish stocking and fishing pressure on fish community structures in French lakes. Fisheries Management and Ecology, 2021, 28 (4), pp.317-327. 10.1111/fme.12476 . hal-03223303

\section{HAL Id: hal-03223303 https://hal.science/hal-03223303}

Submitted on 6 Sep 2021

HAL is a multi-disciplinary open access archive for the deposit and dissemination of scientific research documents, whether they are published or not. The documents may come from teaching and research institutions in France or abroad, or from public or private research centers.
L'archive ouverte pluridisciplinaire HAL, est destinée au dépôt et à la diffusion de documents scientifiques de niveau recherche, publiés ou non, émanant des établissements d'enseignement et de recherche français ou étrangers, des laboratoires publics ou privés. 


\title{
Effects of fish stocking and fishing pressure on fish community structures in French lakes
}

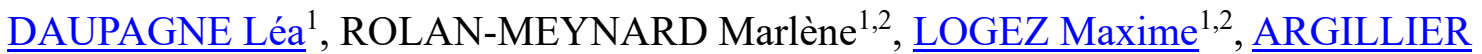 \\ Christine $^{1,2}$
}

Fisheries Management and Ecology, 2021, 28(4), 317-327.

\section{DOI: $10.1111 / f m e .12476$}

https://onlinelibrary.wiley.com/doi/10.1111/fme.12476

${ }^{1}$ INRAE, Aix Marseille Univ, RECOVER, Aix-en-Provence, France

${ }^{2}$ Pôle R\&D « ECLA », Aix-en-Provence, France

\section{Author for correspondance :}

Christine Argillier: christine.argillier@inrae.fr

\section{Publication history}

Version of Record online:

17 March 2021

Manuscript accepted:

5 February 2021

Manuscript revised:

20 Janvier 2021

Manuscript received:

23 September 2020

NB: This version of the manuscript corresponds to the last version before proof-editing by the journal. Some changes made by the editor afterwards may not be present in this version. See online article on the journal's website for the final version of the article. 
Daupagne L., Rolan-Meynard M., Logez M. \& Argillier C. (2021). Effects of fish stocking and fishing pressure on fish community structures in French lakes. Fisheries Management and Ecology. 28(4), 317-327. DOI: 10.1111/fme.12476.

\begin{abstract}
Fish stocking and regulation of fishing activities are widely implemented by freshwater fisheries authorities. who have to protect aquatic communities. The effects of fish management on fish communities have not received sufficient attention. Thanks to two datasets, one from EU Water Framework Directive (WFD) monitoring surveys, and one from a French survey targeting angler's associations, this study investigated the impacts of both fishing intensity and fish stocking on fish communities in French lakes. Both co-inertia analysis and community size spectra analysis, showed that i) for five of the six most stocked fish species in France, stocking does not contribute to the standing stocks and ii) neither fishing intensity nor fish stocking leads to a change in the proportion of large and small fish. The results support the fact that alternative methods should be promoted to enhance native fish populations.
\end{abstract}

Keywords: fish stocking, size spectrum, fishing intensity, standing stocks, community structure

\title{
Introduction
}

Inland waterbodies are of high socioeconomic importance and provide numerous ecosystem services for human society, including drinking water, hydropower generation and fishing (Postel \& Carpenter, 1997). Inland fisheries are of general socio-economical interest (Suuronen \& Bartley, 2014) in particular in the livelihood and diets of many populations, for instance in Asia (De Silva \& Funge-Smith, 2005). In addition to protein supply, freshwater fish provide cultural and recreational services to many people as they contribute to community identities and support non-fishing sectors including boating and the aquarium trade (Arlinghaus, Mehner \& Cowx, 2002; Brugere, Lymer \& Bartley, 2015; Lynch et al., 2016; MEA, 2005; Weithman, 1999; Welcomme \& Naeve, 2001). In most countries, both recreational and professional inland fisheries are regulated by local, regional or national agencies. These management authorities generally adopt various management techniques to both enhance fisheries and protect the aquatic environment. Among them, regulation of fishing intensity to control its impact on targeted populations (Hoffmann, 1996) and stocking aiming at enhancing fish stocks (e.g. Cowx, 1994, 1999; Welcomme \& Bartley, 1998) are the most popular (Cowx, 1994; Welcomme, 1998). The regulation of freshwater fishing is not generally intended to reduce total fishing effort or total catch quota las in marine environment but to impose minimum size limits and/or individual catch limitations to prevent overfishing and secure long-term sustainability of the targeted species (Radomski et al., 2001; Lewin, Arlinghaus \& Mehner, 2006). On the other hand, stocking, the most widespread fishing-associated activities, is often used as a way to compensate for the loss of natural fish by catches and to enhance the fishing experience (Cowx 1994, 1998). For instance, fish stocking was shown to be the first management action in French lakes (Argillier, Pronier \& Changeux, 2002) and a recent update of the situation seems to confirm this (Daupagne et al., 2019). Despite the worldwide importance and frequency of stocking in freshwaters, little attention has been paid to evaluating their real effects in maintaining fish populations.

Indeed, regarding the impacts of these measures, most of the documented studies focused on the impacts of stocked non-native species. Genetic biodiversity is suspected to be endangered due to hybridization between native and non-native closely related fish species (Perry, Lodge \& Feder, 2002). Indeed, introductions of species outside of their normal ranges could induce genetic homogenization of autochthonous species (i.e. a reduction of genetic 
Daupagne L., Rolan-Meynard M., Logez M. \& Argillier C. (2021). Effects of fish stocking and fishing pressure on fish community structures in French lakes. Fisheries Management and Ecology. 28(4), 317-327. DOI: 10.1111/fme.12476.

variability within a species) and therefore be a threat to the integrity of endemic gene pools (Rhymer \& Simberloff, 1996). The most iconic examples of interspecific hybridation are indigenous salmonid fishes of North America (Behnke, 1992). In addition to biotic homogenization, competition could occur between native and non-native fish species, leading ultimately to a disturbance in community composition (Hickley \& Chare, 2004; Van Zyll de Jong, Gibson \& Cowx, 2004; Winfield \& Durie, 2004). Authors suggested that stocking of these non-native species could negatively affect native fish populations and also other resident wildlife populations such as plankton (Parker et al., 2001; Hansen, 2002), invertebrates (Hanisch et al., 2013) or amphibians (Kats \& Ferrer, 2003). Finally, these introductions have sometimes been involved in food web alterations and certain disturbances of whole ecosystem functioning (e.g. Eby et al., 2006; Rahel, 2002; Simon \& Townsend, 2003). Ecological consequences of stocking native species are much less documented in the literature, but are similar to those generated by stocking non-native species. Translocations of populations from one part of its range to another enhance the potential for intraspecific hybridization, resulting in similar genetic homogenization through the assimilation of previously differentiated gene pools (Rhymer \& Simberloff, 1996; Storfer, 1999). The outcomes of fish stocking in terms of its contribution to the standing stock have been rarely studied, especially concerning stockings with roach Rutilus rutilus (Linnaeus), and pike Esox Lucius (L.), for which no assessments of impacts have been made as far as we know. Lack of stocking information presumably limits the evaluation of stocks enhancements through stocking. In addition, existing conclusions are site specific and not necessary convergent (Cucherousset, Paillisson \& Roussel, 2007; Roques et al., 2018). For example, a review from a few Dutch and Finnish studies indicated that stocking with native species is seldom efficient in enhancing fish stocks in lakes, especially concerning pike (Welcomme, Kohler \& Courtenay JR, 1983). These findings were further substantiated by a study in French lowland lakes where no impact of stocking of on the communities of several fish species has been demonstrated (Argillier et al., 2002). Conversely, Hunt et al. (2014) showed a significant positive relationship between angler net catch rate of Chinook salmon Oncorhynchus tshawytscha (Walbaum) with the number of Chinook salmon stocked in an Australian lake and similar results were shown with the Arctic char Salvelinus alpinus (L.) in Lake Geneva (Champigneulle \& Gerdeaux, 1993). Successful rebuilding of populations through hatchery supplementation has also been supposed but actual assessment is often neglected (Cowx, 1994).

The ecological repercussions of fish removal by commercial fisheries and/or angling in inland waters are better documented. For a long time, freshwater fisheries were considered to have little or no impact on fish stocks and, therefore, most studies focused on marine fisheries and their consequences (Jørgensen et al., 2007). Against this common belief, it appeared that several lakes are suffering from overfishing (Post et al., 2003; Post et al., 2008; Allan et al., 2005). High fishing and selective pressure with respect to species, size classes or sex, could lead to a decline of fish populations and affect aquatic ecosystem functions (e.g. Aday et al., 2002; Lester et al., 2003; Longhurst, 2002; Sullivan, 2003; Wilberg et al., 2005). In most cases, anglers prefer specific species, either because they are of high culinary value or because they offer higher fishing challenges (Lewin et al., 2006). Generally, they target large top-predators such as pike, pikeperch Sander lucioperca, (L.), largemouth bass Micropterus salmoides (Lacepède) or salmonids such as brown trout Salmo trutta (L.) (e.g. Arlinghaus \& Mehner, 2005; Post et al., 2002). Therefore, an increase in the exploitation rate of a fish community is expected to lead to a reduction in the abundance of large-bodied predators and to an increase in the abundance of small-bodied prey. This pattern has been observed in many inland waters, mostly of North America and Asia, with assemblages of fish responding to fishing pressure by a change in the size structure, for instance a decline in mean size (e.g. Regier et al., 1999; Welcomme et al., 1999; 2010). In Europe, evidence is scarcer as inland fisheries mainly concerns recreational 
Daupagne L., Rolan-Meynard M., Logez M. \& Argillier C. (2021). Effects of fish stocking and fishing pressure on fish community structures in French lakes. Fisheries Management and Ecology. 28(4), 317-327. DOI: 10.1111/fme.12476.

fishing (Arlinghaus, Mehner \& Cowx, 2002) but this pattern was already observed in some European lakes (i.e. Gassner, Tischler \& Wanzenböck, 2003). A way to precisely assess the impact of fishing intensity on the size structure of fish populations consists in defining a "size spectrum" that is analysing the linear relationship between species abundance and its size classes. Many researchers highlighted that higher fishing intensity results in a steeper slope of the size spectrum of the total fish community (e.g. Daan et al., 2005; Dulvy et al., 2004; Pope \& Knights, 1982). However, most of the studies dealing with the direct impacts of fishingrelated activities on the aquatic environment relate to commercial marine fisheries (Lewin et al., 2006). To our knowledge, no study has genuinely investigated the impacts of fishing intensity on the size spectra of European freshwater fish communities. Improving knowledge on this topic is primordial with regard to the Ecosystem Approach to Fisheries (EAF), the main current reference framework for inland fisheries management (Garcia, 2003), in which all stakeholders commit to developing and managing fisheries so that the development in one sector does not affect negatively the others. This is even more the case within Europe with the introduction of the European Water Framework Directive (WFD) (2000/60/EC), a European environmental legislation that requires European Union countries to achieve "good status" objectives for freshwater and coastal water bodies. Any interventions likely to have an impact on the aquatic ecosystems and on biodiversity should be investigated. This is essential to support ecosystem services whose social and, to a lesser extent, economic dimensions have been mentioned above.

Thus, this study aimed at investigating the impacts of fish stocking and fishing intensity on fish communities in French lakes. The objectives were first to graphically represent and analyse the stocking efforts and the fish community structures of lakes using Principal Component Analyses (PCA) and second to assess the link between fish species abundances and stocking efforts by using a co-inertia analysis (CIA; Dolédec \& Chessel 1994). If fish communities are supported by stocking activities, one would expect a link between the two, but if the fish stocked poorly contribute to fish communities, then no link would be expected. The third objective of this study was to define whether fishing intensity genuinely shapes size structure in French lakes communities. The hypothesis was that fishing intensity, which generally target large fish, could lead to a reduction in the average biomass of the whole community and/or to a change in the proportion of large and small fish. It was also hypothesized that fish stocking could counteract the effect of fishing effort. Size spectra analysis were thus realized to test the effect of fishing intensity on size structure of fish communities, taking into account stocking effort. Gaining such information is crucial to foster a wider understanding of fishing-related activities and their impacts on fish communities, and ultimately to provide efficient management plans.

\section{Material and methods}

\section{Fish community data}

Data on fish communities were collected during gillnet sampling realized as part of the WFD monitoring according to EN 14757 standard (CEN, 2005; 2015). The benthic gillnets used were each $30 \mathrm{~m}$ long and 1.5 high and consisted of $2.5 \mathrm{~m}$ long panels of 12 mesh sizes with $5,6.25,8,10,12.5,15.5,19.5,24,29,35,43,55 \mathrm{~mm}$ knot to knot. Depending on lake area and maximum depth, pre-determined numbers of nets were set randomly at different depths. They were placed, during the summer period, in the evening at dusk and lifted in the morning so as to cover maxima of fish activity (Prchalová et al., 2010). All the fish caught were identified at the species level, measured (nearest $\mathrm{mm}$ total length) and weighted (nearest $\mathrm{g}$ ). 
Daupagne L., Rolan-Meynard M., Logez M. \& Argillier C. (2021). Effects of fish stocking and fishing pressure on fish community structures in French lakes. Fisheries Management and Ecology. 28(4), 317-327. DOI: 10.1111/fme.12476.

\section{Fish stocking and fishing effort}

Information on fish stocking and on fishing effort was collected via questionnaires sent to the 92 French federations of certified associations for fishing and protection of aquatic environments (FDAAPPMA) (i.e. federations gathering local anglers' associations) between December 4, 2017 and January 12, 2018. This survey aimed to improve knowledge about fisheries management practices in lakes, reservoirs and gravel pits, and to identify the species concerned by these actions. Managers were specifically asked to provide a historical overview of fish stocking actions carried out in recent years in each lake they manage. The data collected spread out over a period from one to ten years prior to the gillnet surveys described above, depending on the lakes. For each species concerned, stocking effort was expressed in kilogram of fish per $\mathrm{km}^{2}$ per year. Only the stocking efforts of the five years prior to the gillnet surveys were included in the analysis to obtain consistent and comparable data. The mean annual stocking effort was then calculated for each lake. On the other hand, managers were asked to define the fishing effort as low, moderate or high, according to their knowledge of their lake. This method gave a fairly rough picture of fishing intensity but this classification limited the bias between the judgement of experts from the different federations, whose opinions can be very influenced by the regional context in which fishing is carried out.

\section{Relationship between fish species abundance and fish stocking effort}

Given that the information collected concerned mainly low-altitude lakes $(<1,200$ meters ASL), the few waterbodies located above 1,200 meters were excluded from the analysis to avoid bias due to altitude related differences in fish community structure and environmental characteristics (Pronier \& Irz, 1999). In total, complete datasets with both fish stocking, and community information were available for 48 lowland lakes.

To assess the link between community structure and fish stocking investigations focused on the six most commonly stocked species at those 48 sites: pike, tench Tinca tinca (L.), roach, pikeperch, rainbow trout Oncorhynchus mykiss (W.) and perch Perca fluviatilis (L.). As a first step, two datasets were constructed with fish species as variables and lakes as samples, one with BPUE values of the species caught (Biomass Per Unit Effort, expressed in kilograms of fish per net per 12 hours, $\mathrm{kg} / \mathrm{net} / 12 \mathrm{hr}$ ) and the other with stocking effort information for the same species (kilograms of fish stocked per $\mathrm{km}^{2}$ per year, $\mathrm{kg} / \mathrm{km}^{2} / \mathrm{yr}$ ). Data were expressed in BPUE to homogenize data as stocking information was largely expressed in kilograms. The two data tables were submitted to separate Principal Components Analysis (PCA) based on a correlation matrix.

The relationship between fish stocking activities and abundance of fish species in the communities was then analysed using a co-inertia analysis (CIA). This statistical method assesses the co-structure between two data tables paired by their lines (Dolédec \& Chessel, 1994; Dray, Chessel \& Thioulouse, 2003). As opposed to other canonical analysis such as Redundancy Analysis, co-inertia analysis does not seek to explain one table by another, but to find the link between two tables (Dray et al., 2003) and is, therefore, a reliable method for processing imprecise fish stocking information. This method searches for a representation of the two datasets in a common space by maximizing the covariance between the coordinates of the sites resulting from the two previous PCA analyses (Dolédec \& Chessel 1994) of the stocking table and of the fish community table. To assess the strength of the coupling between the two datasets, the RV coefficient (a multidimensional correlation coefficient; Escoufier, 1973) was calculated and statistical significance was estimated using a Monte Carlo permutation test ( $\mathrm{n}=999)$ (Heo \& Ruben Gabriel, 1998). 
Daupagne L., Rolan-Meynard M., Logez M. \& Argillier C. (2021). Effects of fish stocking and fishing pressure on fish community structures in French lakes. Fisheries Management and Ecology. 28(4), 317-327. DOI: 10.1111/fme.12476.

\section{Relation between size spectra of the communities and fishing effort}

In total, complete datasets with both fishing effort and fish community information were available for 105 waterbodies. Fishing intensity was qualified as low, moderate and high for respectively 18, 53 and 34 lakes. Stocking activities were enumerated by managers on 62 lakes while no activities were carried by managers on 20 lakes. No information regarding the presence or absence of stocking activities was provided for 23 lakes

The size distribution of fish communities was assessed using community size spectra analysis (CSS), a method that defines the linear relationship, most of the time on a log scale, between abundance and body size class (Kerr \& Dickie, 2001). Each fish caught was allocated to a body size class $(1 \mathrm{~cm}$ range) for each lake (regardless of taxonomy since we aim to assess the overall size structure of the fish community assemblage). Size classes at the lower and upper end of the communities' size range were excluded from the analysis to avoid bias due to, respectively, poor retention in the gear and too infrequent captures (i.e. juveniles or small fish can swim through meshes and largest individuals avoid nets more easily) (Axenrot \& Hansson, 2004; Elliott \& Fletcher, 2001; Mehner \& Schulz, 2002) (size range considered $=2.5-96.5$ $\mathrm{cm})$.

For each site, the slope and intercept of the size-spectra were calculated from linear regressions of $\log 10$ CPUE (Catch per Unit Effort, expressed as the number of fish per benthic net per 12 hours) and the rescaled $\log 10$ midpoint of each size class (Figure 1). The $\log$ transformation of the data ensures a linear relationship. The size classes were centred by subtracting the midpoint of the full range of data of the midpoints of all size intervals to avoid the correlation between slope and intercept (Daan et al., 2005). The resulting intercept value represent the "height" of the size spectrum which reflects the community abundance (Trenkel \& Rochet, 2003) while the resulting slope reflects the indirect effects of mortality. Indeed, steepening of the slope is due either to a decrease in the number of large fish, or an increase in the number of small fish, or both.

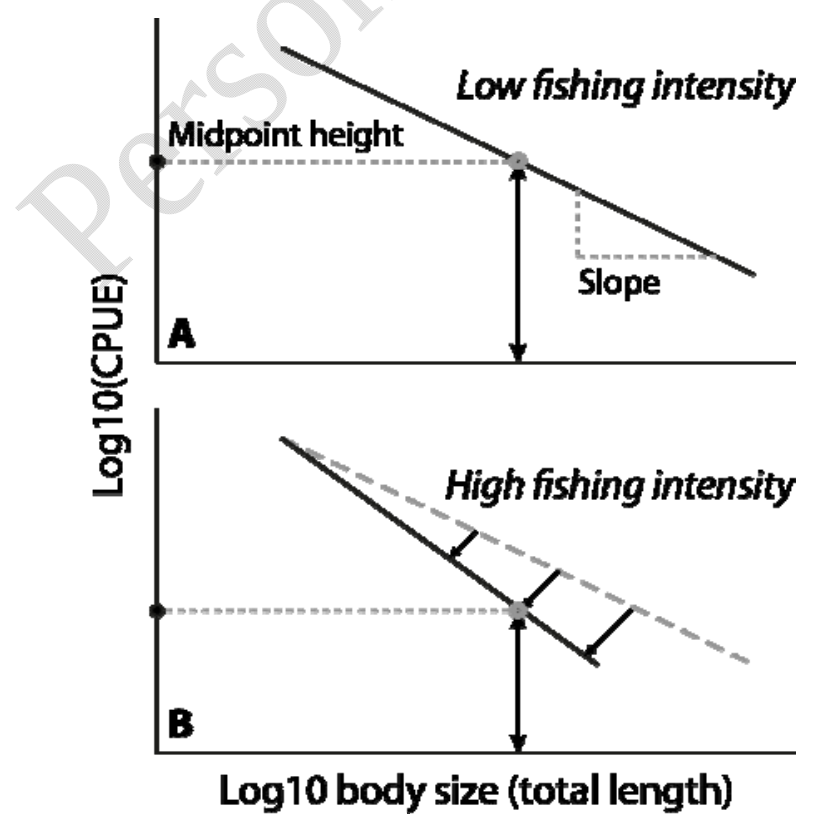

Figure 1. Theoretical representation of a fish community size structure when A: the size-selective fishing is low and when B: the size-selective fishing is high (adapted from Sweeting et al., 2009). 
Daupagne L., Rolan-Meynard M., Logez M. \& Argillier C. (2021). Effects of fish stocking and fishing pressure on fish community structures in French lakes. Fisheries Management and Ecology. 28(4), 317-327. DOI: 10.1111/fme.12476.

First, two-way ANOVA analyses were performed to determine the effect of both fishing intensity classes and stocking actions (expressed in presence/absence) on size spectra metrics along with their interaction. As $F$-tests revealed no significant interaction $(p$-value $>0.05)$ for both metric, we performed additive two-way ANOVAs. For each model, we visually checked whether the linear model assumptions were verified (i.e. normality of residuals and homoscedasticity). When the two-way ANOVA indicated significant main effect, multiple pairwise comparisons were carried out using Tukey post hoc test.

All statistical analysis and graphics were realised using the $\mathrm{R}$ software (R Development Core Team, 2019) ver. 3.4.3. and, in particular, the ade4 package (Chessel, Dufour \& Thioulouse, 2004; Dray \& Dufour, 2007) and the adegraphics package (Siberchicot et al., 2017).

\section{Results}

\section{Relationship between fish stocking and fish community}

The first factorial plane of the PCA performed on stocking effort explained more than onehalf of the total inertia (first axis: $34.7 \%$, second axis: 18.6\%) (Figure A). The first axis displayed a strong association between tench, roach, pike and pikeperch. The second axis opposed the rainbow trout to the perch.

The two first factorial axes of the PCA carried out on fish communities sampling (expressed in BPUE, $\mathrm{kg} / \mathrm{net} / 12 \mathrm{hr}$ ) explained $51 \%$ of the total inertia in the data (Figure $2 \mathrm{~B}$ ). Pike, roach and pikeperch on the right side mainly defined the first axis $(26.6 \%$ of the total inertia) while rainbow trout was located in the left side. The second axis $(24.4 \%$ of the total inertia) opposed perch, tench and pike (positive values) to pikeperch (negative values). Overall, we can distinguish four groups on this factorial design, one consisting of perch and tench, one consisting of pike and roach and the two remaining species appearing as distinct groups.
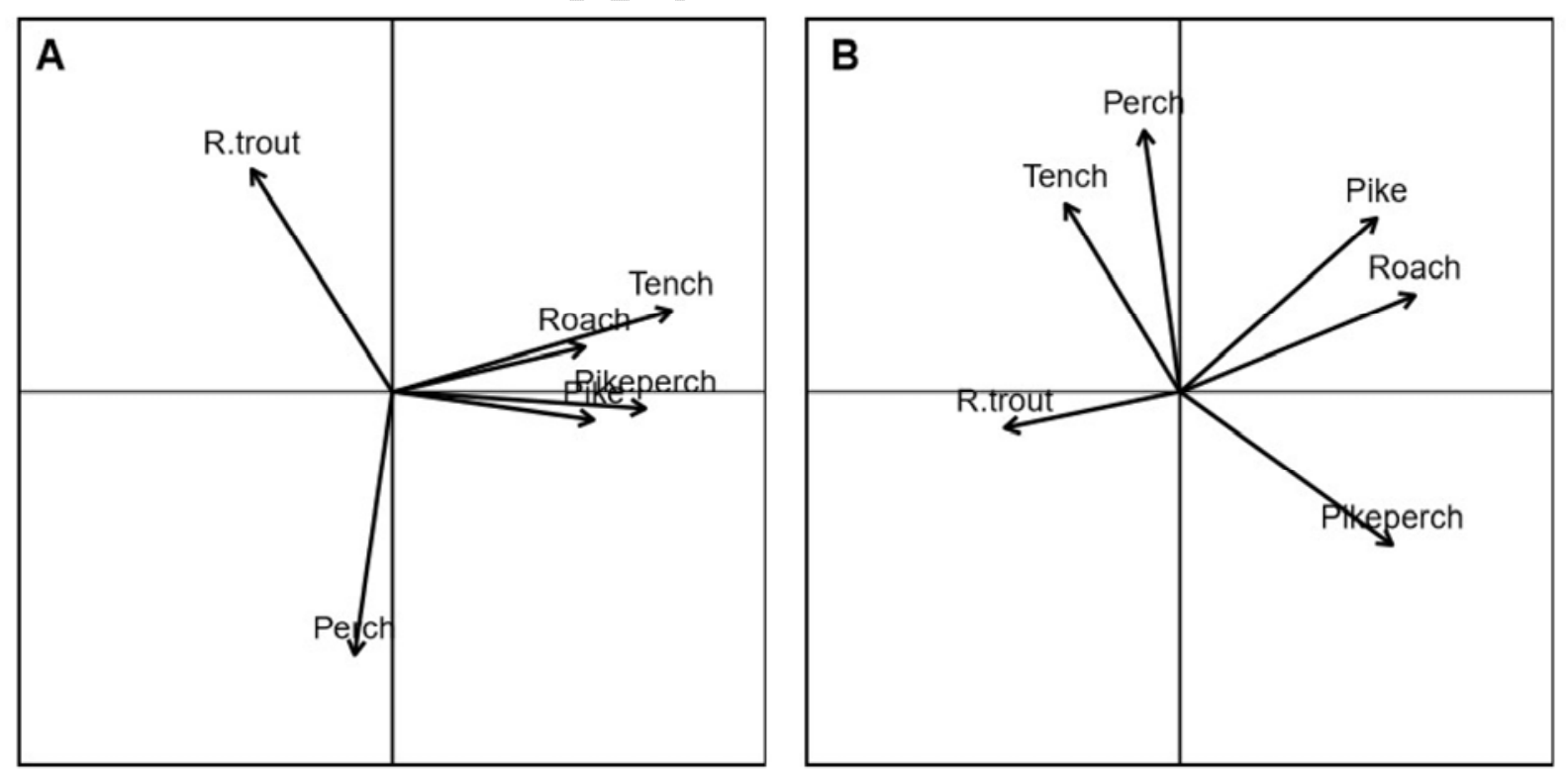

Figure 2. PCA carried out on stocking effort (A) and on mean biomass-per-unit-effort (BPUE) (B) of the six most commonly stocked species $(\mathrm{n}=48)$. The first factorial plane $(\mathrm{A})$ explained about one-half of the total inertia (first axis: $34.68 \%$, second axis: $18.63 \%$ ). The second factorial plane (B) explained $51 \%$ of the total inertia in the data (first axis: $26.55 \%$, second axis: $24.42 \%$ ). 
Daupagne L., Rolan-Meynard M., Logez M. \& Argillier C. (2021). Effects of fish stocking and fishing pressure on fish community structures in French lakes. Fisheries Management and Ecology. 28(4), 317-327. DOI: 10.1111/fme.12476.

The co-inertia analysis coupling the two PCA analyses showed significant but slight link between fish stocking effort and fish community structure as revealed by the low RV value $(0.13, p<0.01$, Monte Carlo test). Figure A and 3B helped interpret this relationship. The first two CIA axes explained $90.7 \%$ and $7.8 \%$ of the inertia of the co-structure. The BPUE of species within communities were partially correlated with stocking activities. Indeed the four standing groups of species observed on the PCA (based on the BPUE) were not observed on the coinertia (Figure 3B). The standing stock of tench and pike were almost not related to stocking as revealed by the very short arrows displayed on Figure 3B. For the rainbow trout, the pattern was even more marked as this species was well represented on the stocking plan (Figure 3A) but not on the plan of the standing stock (Figure 3B). It seemed that the stocking of rainbow trout was opposed to the BPUE of roach (arrows diametrically opposed on Figures 3A and 3B). By contrast, perch was almost not represented on the plan of stockingbut well represented on the negative part of the second axis of the standing stocks alongside roach. For pikeperch, Figures 3 revealed a slight link between stocking and standing stocks, as displayed by the arrows located on the negative part of the first axis, but with different magnitudes (short on the stocking plan but long on the plan of the standing stocks).
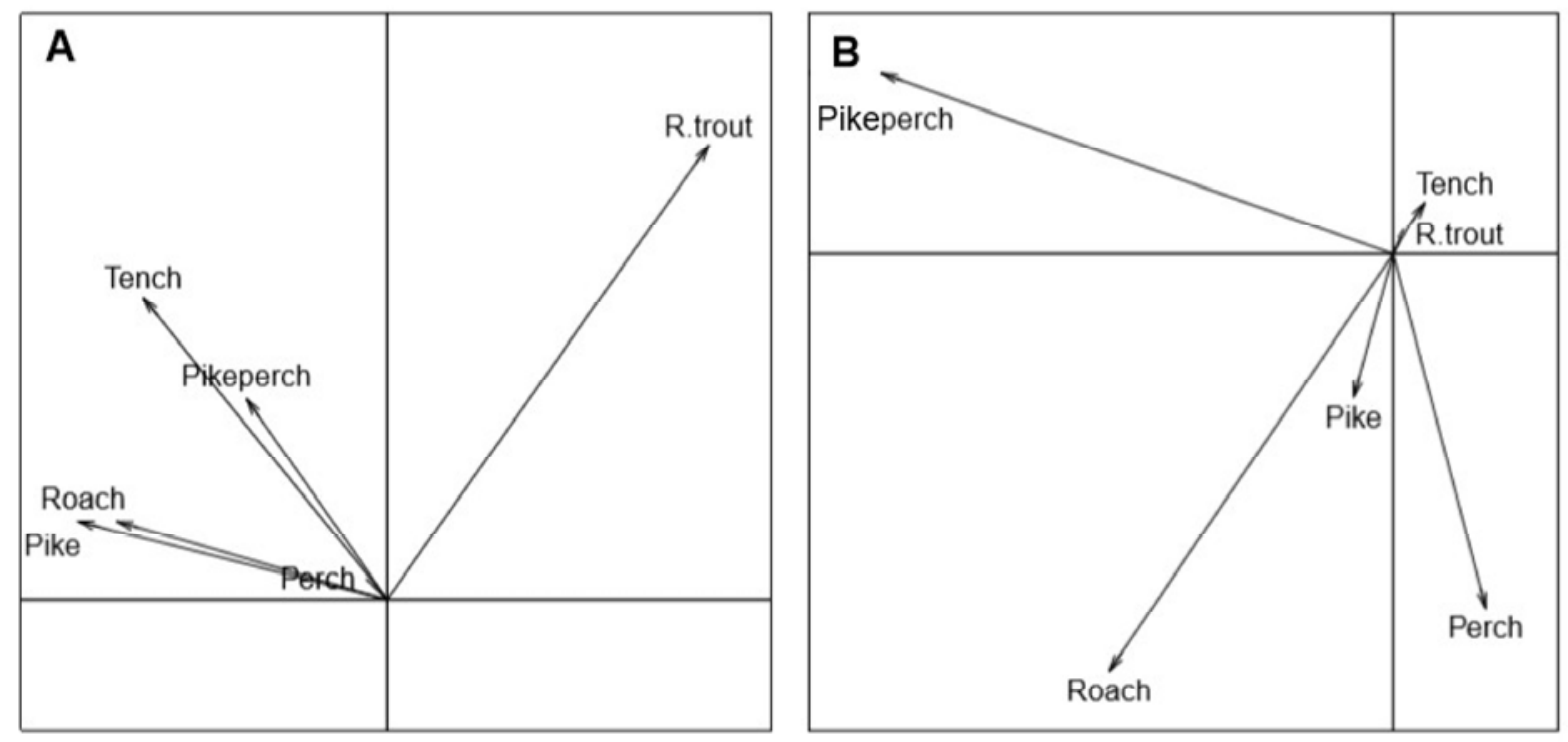

Figure 3. Results of the co-inertia analysis of the relationship between stocking effort (A) and mean biomass-perunit effort (BPUE) (B) of the six most commonly stocked species $(n=48)$. These plots represent the coefficients of the combinations of the variables for each table to define the co-inertia axes. The first two CIA axes explained $90.7 \%$ and $7.8 \%$ of the inertia of the co-structure.

Globally, the standing stocks of perch, pike, roach, tench and rainbow trout were not or were poorly explained by stocking activities. The slight link between standing stocks and stocking activities was also visible on figure 4 , which displayed the correspondence between fish species abundances in the community (end of the arrow) and fish stocking (beginning of the arrow) for each lake (arrows). If the two matched well, the arrow would be short (e.g. reservoir Baradée, BAR32) while if there is no link between the two, the arrow would be long (e.g. reservoir of Chamboux, CHA21). Most of the arrows were long highlighting the mismatched patterns between community structure and fish stocking in the lakes considered in this study. Moreover, no significant correlation was found between the length of arrows and the lake surface area (Spearman's rank correlation, $\rho=0.067, p=0.651$ ). 
Daupagne L., Rolan-Meynard M., Logez M. \& Argillier C. (2021). Effects of fish stocking and fishing pressure on fish community structures in French lakes. Fisheries Management and Ecology. 28(4), 317-327. DOI: 10.1111/fme.12476.

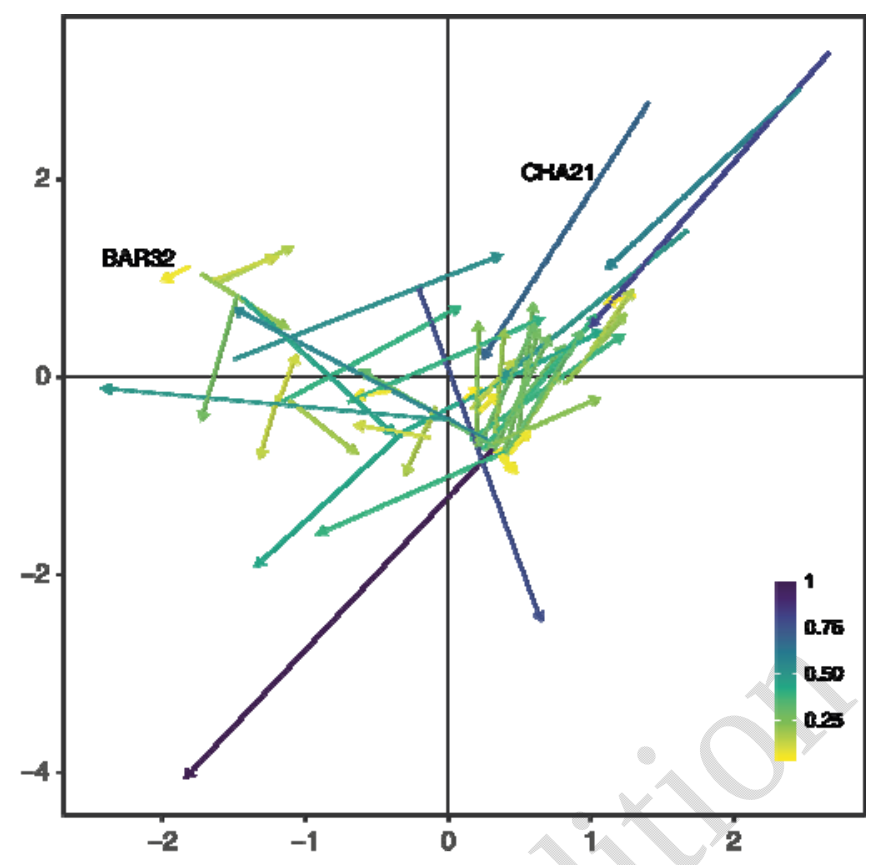

Figure 4. Results of the co-inertia analysis (CIA) of the relationship between stocking effort and mean biomass-per-unit effort (BPUE) of the six most commonly stocked species $(n=48)$. The beginning of the arrow is the position of the waterbody described by the fish stocking dataset and the end of the arrow by the dataset of fish community structure. The length of this arrow is a measure of the strength of the co-structure; the shorter this distance, the better the link between the two structures (rescaled between 0 and 1 for the color gradient). For instance, there is an absence of relation between fish stocking and the species abundance on the reservoir of Chamboux (CHA21) while a relatively strong relationship exists between those two metrics on the reservoir of Baradée (BAR32).

\section{Relationship between fishing intensity, stocking activities and individual size distribution}

The two-way ANOVA on midpoint height metric revealed a significant effect of fishing intensity $\left(\mathrm{F}_{2,100}=4.924, p<0.01\right)$ while stocking activities had no significant effect $\left(\mathrm{F}_{2,100}=2.359, p>0.05\right)$. Tukey post-hoc tests only revealed a significant difference between low and moderate fishing intensity $(p<0.05)$ (Figure 5). 
Daupagne L., Rolan-Meynard M., Logez M. \& Argillier C. (2021). Effects of fish stocking and fishing pressure on fish community structures in French lakes. Fisheries Management and Ecology. 28(4), 317-327. DOI: 10.1111/fme.12476.

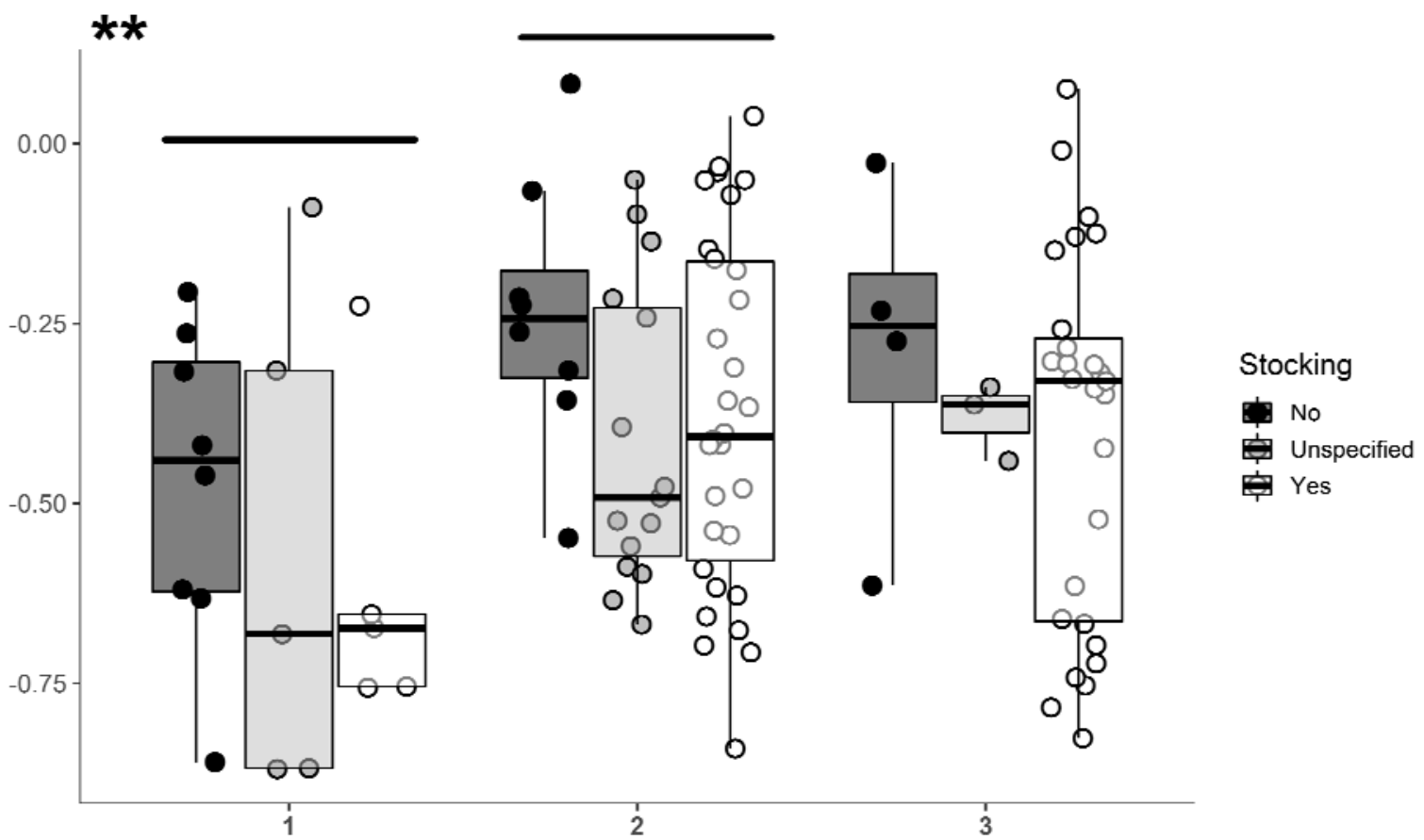

Figure 5. Relationships between midpoint heights and fishing intensity classes for 105 waterbodies. $1=$ low intensity $(\mathrm{n}=18), 2=$ moderate intensity $(\mathrm{n}=53), 3=$ high intensity $(\mathrm{n}=34)$. Tests: two-ways ANOVA and Tukey. **: $\mathrm{p}<0.01$. Bars indicate differences between low intensity and moderate intensity $(\mathrm{p}<0.05)$.

Slopes of size spectra did not vary significantly with fishing intensity $\left(\mathrm{F}_{2,100}=1.404\right.$, $p>0.05)$ or stocking activities $\left(\mathrm{F}_{2,100}=2.275, p>0.05\right)$ (Figure 6$)$.
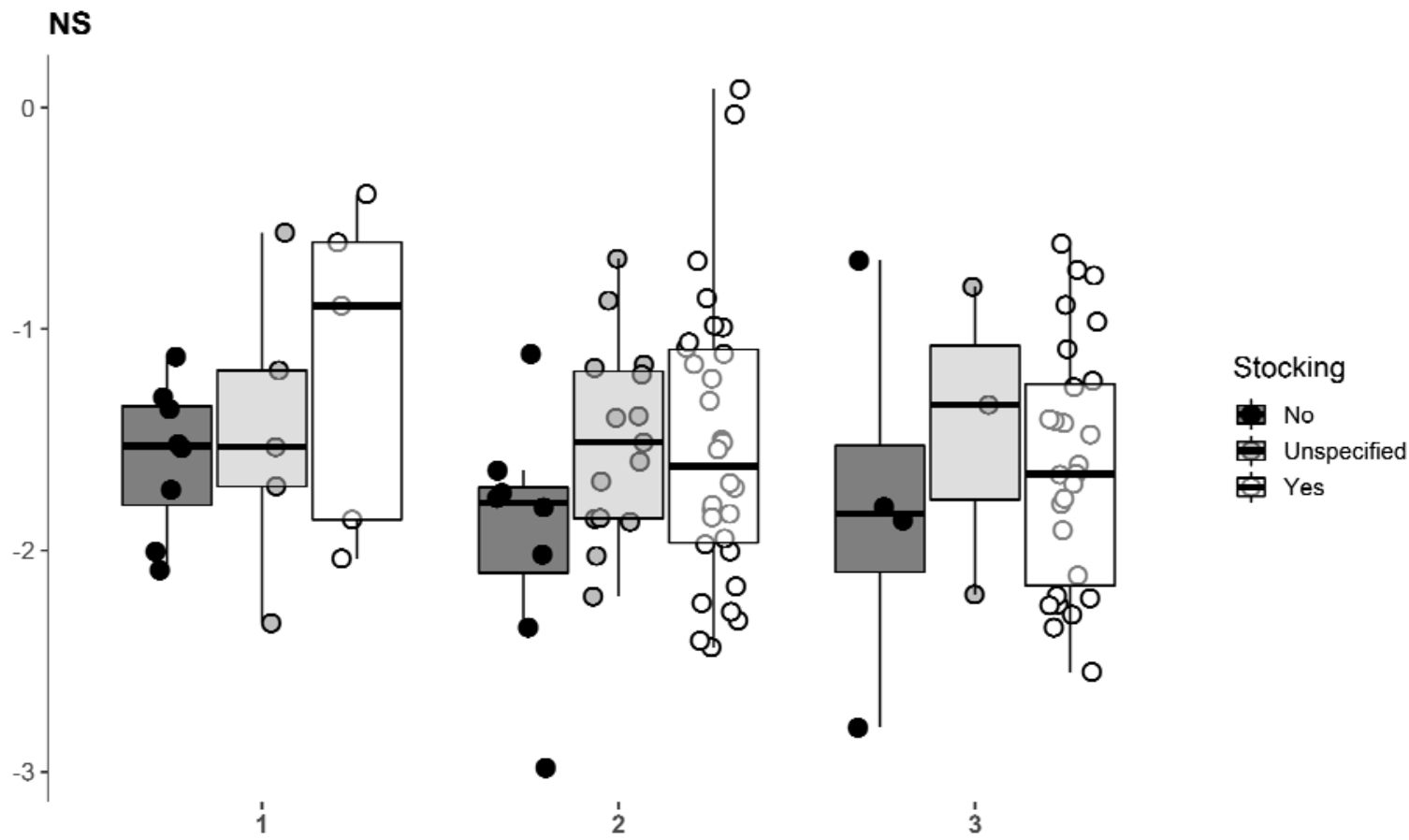

Figure 6. Relationships between slopes and fishing intensity classes for 105 waterbodies. $1=$ low intensity $(n=18)$, $2=$ moderate intensity $(n=53), 3=$ high intensity $(n=34)$. Test: two-ways ANOVA. NS: no significant difference. 
Daupagne L., Rolan-Meynard M., Logez M. \& Argillier C. (2021). Effects of fish stocking and fishing pressure on fish community structures in French lakes. Fisheries Management and Ecology. 28(4), 317-327. DOI: 10.1111/fme.12476.

\section{Discussion and conclusion}

\section{Relationship between fish stocking and fish community}

The survey of inland water stakeholders showed that stocking is currently the main management technique used in France (Daupagne et al., 2019). Stocking is also widespread in many countries as revealed by previous studies conducted in many regions of the world (e.g. Cowx, 1994, 1999; Welcomme \& Bartley, 1998). However, the results of this study, showed that stocked individuals do not contribute to any increase in French lake species density or at least very little. Hence, any changes in standing stocks of pike, rainbow trout, perch and tench in the French lakes studied were not explained by stocking activities.

Concerning pike stocking, the results of this study agree with previous observations. Indeed, Snow (1974) reported that stocking adults in Murphy Flowage lake (Wisconsin, USA), which host a natural stock of pike, doubled pike density. Nevertheless, the pike stock declined two years after stocking to reach values recorded before stocking event and even below. Snow (1974) also observed that anglers captured $78 \%$ of the stocked adult pike in the first year after stocking. Similarly, Carlander (1958) highlighted that fishers captured almost $20 \%$ of stocked adult pike within the first six weeks following the opening of the fishing season. In addition stocking could also raise the level of cannibalism and thus reduced the abundance of young life stages (Pereira et al., 2017). Therefore, stocking of adult pike appears to be a suitable option to allow short-term enhancement of catches by anglers but is ineffective in bringing about a longterm increase in the stock. No studies have shown a positive effect of pike stocking on future recruitment; it is assumed that stocked individuals and their offspring have lower fitness than natural populations and that new recruits would go through the same habitat bottlenecks that were probably responsible for the weakness of natural fish stocks (Guillerault et al., 2018).

The efficiency of stocking programs for salmonids are better documented, although contrasted (Vehanen, 1997). In French lakes, rainbow trout is a non-native species which usually does not reproduce in natural conditions. Only the rainbow trout population from the artificial Bouillouses reservoir, a high-altitude lake in the southern Pyrenees, has become naturalized and formed a genuine self-sustaining population (Delacoste et al., 1997). According to the managers who responded to our questionnaire, rainbow trout is generally introduced at a legal catch size. This suggests that most of individuals are caught by anglers shortly after their release in the lakes, but the lack of consistent data on the quantity of fish caught by anglers limits the ability to assess the role played by fish removals.

No reference was found regarding the impact of roach stocking on population abundance. In French lakes, roach is often introduced with piscivorous fish in order to improve their prey abundance. It is therefore not surprising that roach abundance was not correlated with stocking intensity. Moreover, roach is highly abundant in French lakes which could have limited the ability to detect the effect of stocking on the abundance of this species due to a dilution effect. Similarly, references are lacking regarding perch and tench. For these species, it can be hypothesised that if the fishing intensity is high, stocking allows to maintain their abundance in the communities at best.

In this study, only standing stocks of pikeperch were shown to be slightly correlated with stocking. Rapid growth of this species may decrease its vulnerability to predation, decrease the risk of winter mortality, and accordingly increase the potential yield of stocking. However, the effectiveness of pikeperch stocking has been reported to be very variable among European lakes (Erm, 1981; Lehtonen, Miina \& Frisk, 1984; Ruuhijärvi, Salminen \& Nurmio, 1996). Stocking success would vary considerably across years and lakes, relying on: water quality, lake area, 
Daupagne L., Rolan-Meynard M., Logez M. \& Argillier C. (2021). Effects of fish stocking and fishing pressure on fish community structures in French lakes. Fisheries Management and Ecology. 28(4), 317-327. DOI: 10.1111/fme.12476.

lake depth and particularly on size, age and abundance of the stocked fish (Lehtonen, Miina \& Frisk, 1984). It is possible that, in spite of its fishing interest, this species encounters favourable conditions to its development in the studied lakes, most of them being reservoirs with vacant niches left by the native river species.

From an economic perspective, the conclusions of this study call into question the interest of stocking programs at national scale, as the yield of this support to populations is globally low and unpredictable. What emerges from the scientific literature is that the success or failure of a stocking program is essentially a matter of local environmental conditions. For example, lake area appeared to be an important parameter affecting the efficiency of fish stocking (Fayram, Hansen \& Nate, 2005) but that was not verified in this study. There are few examples of inland stocking that are considered as an economic success and that forms the basis of important quasi-aquacultural fisheries in many tropical lakes, primarily in Asia (Welcomme and Bartley, 1998). Thai reservoirs, for instance, are often referred as "cost-effective" as stocked fish are thought to contribute to $\$ 2$ million worth of carp caught each year although the relative contribution of the stocked fish to the fishery has yet to be assessed (Welcomme and Bartley, 1998). It is therefore urgent to continue collecting data on a large number of sites to gain a better understanding of the processes involved in the success or failure of a stocking program. Furthermore, standing stocks appeared to remain stable or to even improve in areas where stocking has ceased (Welcomme et al., 1983). Enhancing habitat quality seems a more efficient management tool to improve population sustainability (Marttila et al., 2019). The creation of artificial spawning structures rather than stocking large numbers of individuals could be an efficient and economical solution for the long-term establishment of fish populations (Erm, 1981). Particular attention must be given to the specific substrate requirements and preferences of the target species. Some substrate-spawning species are opportunistic in choice of substrate such as perch (Snickars et al., 2010) and pikeperch (Lappalainen, Dörner \& Wysujack, 2003) which can spawn on roots, vegetation, sand, gravel or turf. By contrast, some species are choosier and optimal spawning substrate is submerged macrophytes in shallow waters for specific vegetation-spawning fish such as pike (Casselman \& Lewis, 1996) and tench (Rowe, 2004). However, habitat restoration in lakes can be expensive and difficult, in particular in reservoirs exhibiting water level fluctuations, particularly for fish species that spawn very close to the water surface such as roach (Gillet \& Dubois, 1995). All these particularities must be taken into account to ensure that fish habitats are appropriately managed.

\section{Relationship between fishing intensity and individual size distribution}

The results of this study showed the impact of fishing intensity on the midpoint heights of the size spectra. Interpretation of this result is complex. Indeed, the midpoints could not be interpreted as an effect of exploitation (reduced predation on small-sized fish) as midpoints tends to be lower when fishing intensity is lower. The observed changes are probably induced by an effect of the environment. Hall \& Greenstreet (1996) suggested that detrimental environmental conditions could induce size-independent reduction in species richness without an associated change in slope of size spectra. For instance, water levels fluctuation in large reservoirs is a problematic factor for natural recruitment of fish (Kahl et al., 2008). Lake morphometry is also important in determining habitat complexity and habitat availability for fish. Deep lakes appear to display lower midpoints (Emmrich et al., 2011), suggesting a lower abundance of fish in those lakes.

Second, this study showed no statistical evidence of impacts of fish stocking on the slope of length spectra of fish communities in French lakes. This result was predictable as stocked individuals do not contribute to the increase in standing stocks (see previous section). On the 
Daupagne L., Rolan-Meynard M., Logez M. \& Argillier C. (2021). Effects of fish stocking and fishing pressure on fish community structures in French lakes. Fisheries Management and Ecology. 28(4), 317-327. DOI: 10.1111/fme.12476.

other hand, observation of no statistical decline in the slope of length spectra of fish species caught with increasing fishing intensity was surprising. Indeed, it is now widely accepted that marine fishing activities resulting in large-bodied individuals or species' removal, steepen the size spectra of fish community (e.g. Daan et al., 2005; Dulvy et al., 2004; Pope \& Knights, 1982). Similarly, numerous lake fisheries are more or less impacting size structure of targeted species (Serns \& Kempinger, 1981; Kolding et al., 2016). These differential impacts were explained by fishing intensity and selectivity, fishing regulations or management strategies (Kolding et al., 2016, Rypel et al., 2016; Tefera et al., 2019). Our results does not exclude a possible local impact of fisheries on the populations' size but suggest that the degree of recreational fishing pressure on most of the French lakes is too low to impact size structure significantly. This result is in accordance with a German study, which showed that lake-use intensity (anthropogenic shoreline modifications and fishing effort) had no impact on the size structure of fish communities (Emmrich et al., 2011) and can probably be generalised to the whole European context where a decline in commercial but also recreational activities was noticed (Cowx, 2015). However, this result could be explained in multiple ways. First, it is possible that a true difference exists but that our analysis failed to detect it because of the small sample size, especially concerning the modality "low fishing intensity" $(n=18)$. Second, the estimations of fishing pressure were based on the statements of inland water stakeholders and have been classified into three categories. This necessarily induces a bias, because different observers can interpret the fishing intensity differently, which can distort the estimation of fishing pressure. In addition, the possibility that the three categories were oversimplified to detect subtle impacts of fishing on size structure cannot be ruled out. The limited research investigating the impacts of fishing intensity in temperate freshwater systems express this metric as the fishing effort (e.g. the number of anglers) per unit area and per unit of time, information both difficult and time consuming to collect in freshwater recreational fishing context especially in a large scale study such as ours.

Third, numerous other biotic and abiotic factors may further affect size structure of populations. For example, Quintana et al. (2015) showed that size distributions of fish were more diverse when resource availability was low, highlighting that competitive interactions induce diversification of communities by size. Greater predation, on the other hand, seems to reduce size diversity of prey. It has also been shown that the slope of the normalised length spectra of a lake fish community were flatter and size diversity was higher in lakes with both higher abundance of large fish and higher level of nutrients (Emmrich et al., 2011).

Finally, part of the data used here are obtained from the application of the European Standard Gillnets used in the WFD monitoring programs of French lakes, and this is a selective method. This method is selective towards species according their mobility and body shape. For instance, pike is a species highly targeted by stocking programs but little captured by CEN gillnets which makes the evaluation of these programs difficult. In addition, the presence and the number of small and large individuals cannot be precisely estimated in particular those smaller than $80 \mathrm{~mm}$ that appeared to be underrepresented (Olin, Malinen \& Ruuhijärvi, 2009; Prchalová et al., 2009) and that are thus often left out of size spectra analysis, including ours. Similarly, the gillnet catches of large fish (as soon as they exceed $400 \mathrm{~mm}$ ) and which represent a significant part of individuals targeted by anglers and fishermen, seemed to be underrepresented in terms of abundance, fish biomass and size composition (Šmejkal et al., 2015). As part of the study cited above, a novel type of multimesh gillnet consisting of four large mesh sizes $(70,90,110$ and $135 \mathrm{~mm}$ ) have been set up. Extending the mesh size range of gillnets would improve the biomass estimates of the largest fish (Šmejkal et al., 2015) that are mostly targeted by anglers. 
Daupagne L., Rolan-Meynard M., Logez M. \& Argillier C. (2021). Effects of fish stocking and fishing pressure on fish community structures in French lakes. Fisheries Management and Ecology. 28(4), 317-327. DOI: 10.1111/fme.12476.

To conclude, the large dataset analyses in this study seem to confirm the poor efficiency of the stocking actions in the French lakes. In case such stocking should be maintained, they should be based on a greater understanding on the factors behind the successes and failures of these practices, which require improvement of stocking data collection and analysis. This study also fails in demonstrating a clear effect of fishing intensity on fish community size distributions. Those results suggest the need to think more carefully about environmental, biological and management related data collection if we are to accurately quantify the consequences of fishing activities on fish communities. In particular, future studies should concentrate on the quantification of an effective fishing effort in lakes, thereby improving the estimation of the actual fishing pressure on standing stocks. In addition it would be important to have a special focus on fish species and sizes targeted by anglers. Obtaining such information is essential and requires the implication of all inland water stakeholders. The development of citizen sciences is a promising way to improve this knowledge.

\section{Acknowledgments}

This study, covering more than 100 lakes and an entire country, was made possible thanks to the continuous work of several of our collaborators who collected fish during sampling campaigns as part of the WFD monitoring surveys. We thanks Nathalie Reynaud and Julien Dublon for their help in data entry and initial data correction. Furthermore, we thank the 92 French federations of certified associations for fishing and protection of aquatic environments (FDAAPPMA) who took the time to complete our questionnaire and to provide essential information on their activities. We also gratefully acknowledge the two anonymous reviewers and Dr. Robin Welcomme for their valuable comments and suggestions that helped improve our manuscript. 
Daupagne L., Rolan-Meynard M., Logez M. \& Argillier C. (2021). Effects of fish stocking and fishing pressure on fish community structures in French lakes. Fisheries Management and Ecology. 28(4), 317-327. DOI: 10.1111/fme.12476.

\section{References}

Aday, D., Kush, C., Wahl, D., \& Philipp, D. (2002). The influence of stunted body size on the reproductive ecology of bluegill Lepomis macrochirus. Ecology of Freshwater Fish, 11(3), 190-195.

Allan, J. D., Abell, R., Hogan, Z., Revenga, C., Taylor, B. W., Welcomme, R. L., \& Winemiller, K. (2005). Overfishing of inland waters. BioScience, 55(12), 1041-1051.

Argillier, C., Pronier, O., \& Changeux, T. (2002). Fishery management practices in French lakes. In I. G. Cowx (Ed.), Management and Ecology of Lake and Reservoir Fisheries (pp 312-321). Blackwell Science, Oxford.

Arlinghaus, R., Mehner, T., \& Cowx, I. G. (2002). Reconciling traditional inland fisheries management and sustainability in industrialized countries, with emphasis on Europe. Fish and fisheries, 3(4), 261-316.

Arlinghaus, R., \& Mehner, T. (2005). Determinants of management preferences of recreational anglers in Germany: habitat management versus fish stocking. Limnologica, 35(1-2), 217.

Axenrot, T., \& Hansson, S. (2004). Seasonal dynamics in pelagic fish abundance in a Baltic Sea coastal area. Estuarine, Coastal and Shelf Science, 60(4), 541-547.

Behnke, R. J. (1992). Native Trout of Western North America. American Fisheries Society Monograph 6, American Fisheries Society

Brugere, C., Lymer, D., \& Bartley, D. (2015). Ecosystem services in freshwater fish production systems and aquatic ecosystems: Recognizing, demonstrating and capturing their value in food production and water management decisions. TEEB Agriculture \& Food, UNEP, Geneva.

Carlander, K.D. (1958). Disturbance of the predator - prey balance as a management technique. Transactions of the American Fisheries Society, 87(1), 34-38.

Casselman, J. M., \& Lewis, C. A. (1996). Habitat requirements of northern pike (Essox lucius). Canadian Journal of Fisheries and Aquatic Sciences, 53(S1), 161-174.

Champigneulle, A., \& Gerdeaux, D. (1993). The recent rehabilitation of the Arctic charr (Salvelinus alpinus) fishery in Lake Geneva. In: I.G. Cowx (ed.), Rehabilitation of Freshwater Fisheries (pp. 293-301). Oxford: Fishing News.

Chessel, D., Dufour, A., \& Thioulouse, J. (2004). The ade4 package - I: One-table methods. $R$ News, 4(1), 5-10.

Cowx, I. G. (1994). Stocking strategies. Fisheries Management and Ecology, 1(1), 15-30.

Cowx, I. G. (1998). Stocking and introduction of fish. Oxford: Fishing News Books, Blackwell Science.

Cowx, I. G. (1999). An appraisal of stocking strategies in the light of developing country constraints. Fisheries Management and Ecology, 6(1), 21-34.

Cowx, I. G. (2015). Characterisation of inland fisheries in Europe. Fisheries Management and Ecology, 22(1), 78-87.

Cucherousset, J., Paillisson, J. M., \& Roussel, J. M. (2007). Using PIT technology to study the fate of hatchery-reared YOY northern pike released into shallow vegetated areas. Fisheries Research, 85(1-2), 159-164.

Daan, N., Gislason, H., G. Pope, J., \& Rice, J. C. (2005). Changes in the North Sea fish community: evidence of indirect effects of fishing? ICES Journal of marine Science, 62(2), 177-188.

Daupagne, L., Rolan-Meynard, M., Dublon, J., \& Argillier, C. (2019). Enquête sur la gestion piscicole des plans d'eau français. Irstea, pp. 59. 
Daupagne L., Rolan-Meynard M., Logez M. \& Argillier C. (2021). Effects of fish stocking and fishing pressure on fish community structures in French lakes. Fisheries Management and Ecology. 28(4), 317-327. DOI: 10.1111/fme.12476.

De Silva, S., \& Funge-Smith, S. (2005). A review of stock enhancement practices in the inland water fisheries of Asia. Asia-Pacific Fishery Commission RAP Publication2005/12, pp. 93. Bangkok, Thailand.

Delacoste, M., Baran, P., Lascaux, J. M., Abad, N., \& Besson, J. P. (1997). Bilan des introductions de salmonidés dans les lacs et ruisseaux d'altitude des Hautes-Pyrénées. Bulletin Français de la Pêche et de la Pisciculture, 344-345, 205-219.

Dolédec, S., \& Chessel, D. (1994). Co-inertia analysis: An alternative method for studying species-environment relationships. Freshwater Biology, 31(3), 277-294.

Dray, S., Chessel, D., \& Thioulouse, J. (2003). Co-inertia analysis and the linking of ecological data tables. Ecology, 84(11), 3078-3089.

Dray, S., \& Dufour, A.-B. (2007). The ade4 package: Implementing the duality diagram for ecologists. Journal of statistical software, 22(4), 1-20.

Dulvy, N., Polunin, N. V., Mill, A., \& Graham, N. A. (2004). Size structural change in lightly exploited coral reef fish communities: Evidence for weak indirect effects. Canadian journal of fisheries and aquatic sciences, 61(3), 466-475.

Eby, L. A., Roach, W. J., Crowder, L. B., \& Stanford, J. A. (2006). Effects of stocking-up freshwater food webs. Trends in Ecology \& Evolution, 21(10), 576-584.

Elliott, J., \& Fletcher, J. (2001). A comparison of three methods for assessing the abundance of Arctic charr, Salvelinus alpinus, in Windermere (northwest England). Fisheries Research, 53(1), 39-46.

Emmrich, M., Brucet, S., Ritterbusch, D., \& Mehner, T. (2011). Size spectra of lake fish assemblages: responses along gradients of general environmental factors and intensity of lake-use. Freshwater Biology, 56(11), 2316-2333.

Erm, V. (1981). Populâcionnye parametry i ocenka stepeni èkspluatacii zapasov sudaka v Pârnuskoj buhte.[Population parameters and estimation of the exploitation rate of pikeperch in Pärnu Bay.]. Rybohozâjstviennye issledovaniâ v bassejne Baltijskogo morâ, Riga, 16, 46-63.

Escoufier, Y. (1973). Le traitement des variables vectorielles. Biometrics, 29, 751-760.

Fayram, A. H., Hansen, M. J., \& Nate, N. A. (2005). Determining optimal stocking rates using a stock-recruitment model: An example using walleye in Northern Wisconsin. North American Journal of Fisheries Management, 25(4), 1215-1225.

Garcia, S. M. (2003). The ecosystem approach to fisheries: issues, terminology, principles, institutional foundations, implementation and outlook: Food \& Agriculture Org.

Gassner, H., Tischler, G., \& Wanzenböck, J. (2003). Ecological integrity assessment of lakes using fish communities-suggestions of new metrics developed in two Austrian prealpine lakes. International Review of Hydrobiology: A Journal Covering all Aspects of Limnology and Marine Biology, 88(6), 635-652.

Gillet, C., \& Dubois, J. P. (1995). A survey of the spawning of perch (Perca fluviatilis), pike (Esox lucius), and roach (Rutilus rutilus), using artificial spawning substrates in lakes. Hydrobiologia, 300(1), 409-415.

Guillerault, N., Hühn, D., Cucherousset, J., Arlinghaus, R., \& Skov, C. (2018). Stocking for pike population enhancement. In C. Skov, \& P. A. Nilsson (Eds.), Biology and Ecology of Pike (pp. 215-248). CRC Press, Boca Rato, Florida, USA.

Hall, S., \& Greenstreet, S. (1996). Global diversity and body size. Nature, 383, 132-133.

Hanisch, J. R., Tonn, W. M., Paszkoswki, C. A., \& Scrimgeour, G. J. (2013). Stocked trout have minimal effects on littoral invertebrate assemblages of productive fish-bearing lakes: a whole-lake BACI study. Freshwater Biology, 58(5), 895-907.

Hansen, M. M. (2002). Estimating the long - term effects of stocking domesticated trout into wild brown trout (Salmo trutta) populations: An approach using microsatellite DNA analysis of historical and contemporary samples. Molecular Ecology, 11(6), 1003-1015. 
Daupagne L., Rolan-Meynard M., Logez M. \& Argillier C. (2021). Effects of fish stocking and fishing pressure on fish community structures in French lakes. Fisheries Management and Ecology. 28(4), 317-327. DOI: 10.1111/fme.12476.

Heo, M., \& Ruben Gabriel, K. (1998). A permutation test of association between configurations by means of the RV coefficient. Communications in Statistics-Simulation and Computation, 27(3), 843-856.

Hickley, P., \& Chare, S. (2004). Fisheries for non - native species in England and Wales: angling or the environment? Fisheries Management and Ecology, 11(3-4), 203-212.

Hoffmann, R. C. (1996). Economic development and aquatic ecosystems in medieval Europe. The American Historical Review, 101(3), 631-669.

Hunt, T. L., Giri, K., Brown, P., Ingram, B. A., Jones, P. L., Laurenson, L. J., \& Wallis, A. M. (2014). Consequences of fish stocking density in a recreational fishery. Canadian Journal of Fisheries and Aquatic Sciences, 71(10), 1554-1560.

Jørgensen, C., Enberg, K., Dunlop, E. S., Arlinghaus, R., Boukal, D. S., Brander, K., Ernande, B., Gardmark, A. G., Johnston, F., Matsumura, S., Pardoe, H., Raab, K., Silva, A., Vainikka, A., Dieckmann, U., Heino, M., \& Rijnsdorp A. D.(2007). Ecology: managing evolving fish stocks. Science, 318(5854), 1247-1248.

Kahl, U., Hülsmann, S., Radke, R. J., \& Benndorf, J. (2008). The impact of water level fluctuations on the year class strength of roach: Implications for fish stock management. Limnologica, 38(3-4), 258-268.

Kats, L. B., \& Ferrer, R. P. (2003). Alien predators and amphibian declines: Review of two decades of science and the transition to conservation. Diversity and distributions, 9(2), 99-110.

Kerr, S. R., \& Dickie, L. M. (2001). The biomass spectrum: A predator-prey theory of aquatic production. Columbia University Press, New-York, New-York, USA.

Kolding, J., Jacobsen, N. S., Andersen, K. H., \& van Zwieten, P. A. M. (2016). Maximizing fisheries yields while maintaining community structure. Canadian Journal of Fisheries and Aquatic Sciences, 73, 644-655.

Lappalainen, J., Dörner, H., \& Wysujack, K. (2003). Reproduction biology of pikeperch (Sander lucioperca (L.)) - a review. Ecology of Freshwater Fish, 12(2), 95-106.

Lehtonen, H., Miina, T., \& Frisk, T. (1984). Natural occurrence of pike-perch (Stizostedion lucioperca (L.)) and success of introductions in relation to water quality and lake area in Finland. Aqua Fennica, 14(2), 189-196.

Lester, N. P., Marshall, T. R., Armstrong, K., Dunlop, W. I., \& Ritchie, B. (2003). A broad-scale approach to management of Ontario's recreational fisheries. North American Journal of Fisheries Management, 23(4), 1312-1328.

Lewin, W.-C., Arlinghaus, R., \& Mehner, T. (2006). Documented and potential biological impacts of recreational fishing: insights for management and conservation. Reviews in Fisheries Science, 14(4), 305-367.

Longhurst, A. (2002). Murphy's law revisited: longevity as a factor in recruitment to fish populations. Fisheries Research, 56(2), 125-131.

Lynch, A. J., Cooke, S. J., Deines, A. M., Bower, S. D., Bunnell, D. B., Cowx, I. G., Nguyen, V. M., Nohner, J., Phouthavong, K., Riley, B., Rogers, M. W., Taylor, W. W., Woelmer, W., Youn, S.-J., \& Douglas Jr, B. T. (2016). The social, economic, and environmental importance of inland fish and fisheries. Environmental Reviews, 24(2), 115-121.

Marttila, M., Louhi, P., Huusko, A., Vehanen, T., Mäki-Petäys, A., Erkinaro, J., Syrjänen, J. T., \& Muotka, T. (2019). Synthesis of habitat restoration impacts on young-of-the-year salmonids in boreal rivers. Reviews in Fish Biology and Fisheries, 29, 513-527.

MEA. (2005). Ecosystems and Human Well-Being: Synthesis. Island Press, Washington, DC.

Mehner, T., \& Schulz, M. (2002). Monthly variability of hydroacoustic fish stock estimates in a deep lake and its correlation to gillnet catches. Journal of Fish Biology, 61(5), 11091121. 
Daupagne L., Rolan-Meynard M., Logez M. \& Argillier C. (2021). Effects of fish stocking and fishing pressure on fish community structures in French lakes. Fisheries Management and Ecology. 28(4),

317-327. DOI: 10.1111/fme.12476.

Olin, M., Malinen, T., \& Ruuhijärvi, J. (2009). Gillnet catch in estimating the density and structure of fish community - comparison of gillnet and trawl samples in a eutrophic lake. Fisheries Research, 96(1), 88-94.

Parker, B. R.., Schindler, D. W., Donald, D. B., \& Anderson, R. S. (2001). The effect of stocking and re-moval of a nonnative salmonid on the plankton of an alpine lake. Ecosystems, 4(4), 334-345.

Pereira, L. S., Agostinho, A. A., \& Winemiller, K. O. (2017). Revisiting cannibalism in fishes. Reviews in Fish Biology and Fisheries, 27, 499-513.

Perry, W. L., Lodge, D. M., \& Feder, J. L. (2002). Importance of hybridization between indigenous and nonindigenous freshwater species: An overlooked threat to North American biodiversity. Systematic Biology, 51(2), 255-275.

Pope, J., \& Knights, B. (1982). Simple models of predation in multi-age multispecies fisheries for considering the estimation of fishing mortality and its effects. Canadian Special Publications in Fisheries and Aquatic Sciences, 59, 64-69.

Post, J. R., Sullivan, M., Cox, S., Lester, N. P., Walters, C. J., Parkinson, E. A., Paul, A. J., Jackson, L., \& Shuter, B. J. (2002). Canada's recreational fisheries: The invisible collapse? Fisheries, 27(1), 6-17.

Post, J. R., Mushens, C., Paul, A., \& Sullivan, M. (2003). Assessment of alternative harvest regulations for sustaining recreational fisheries: Model development and application to bull trout. North American Journal of Fisheries Management, 23(1), 22-34.

Post, J. R., Persson, L., Parkinson, E. V., \& Kooten, T. V. (2008). Angler numerical response across landscapes and the collapse of freshwater fisheries. Ecological Applications, 18(4), 1038-1049.

Postel, S., \& Carpenter, S. (1997). Freshwater ecosystem services. In G.C. Daily (Ed.), Nature's services: Societal dependence on natural ecosystems (pp. 195-214). Washington, DC: Island Press.

Prchalová, M., Kubečka, J., Ř́ha, M., Mrkvička, T., Vašek, M., Jůza, T., Kratochvíl, M., Peterka, J., Draštík, V., \& Kř́žek, J. (2009). Size selectivity of standardized multimesh gillnets in sampling coarse European species. Fisheries Research, 96(1), 51-57.

Prchalová, M., Mrkvička, T., Kubečka, J., Peterka, J., Čech, M., Muška, M., Kratochvíl, M.,\& Vašek, M. (2010). Fish activity as determined by gillnet catch: a comparison of two reservoirs of different turbidity. Fisheries Research, 102(3), 291-296.

Pronier, O., \& Irz, P. (1999). Relationship between fish populations and physical characteristics of French lakes and reservoirs. Sustainable Lake Management - 8th International Conference on the Conservation and Management of lakes, Copenhague (Denmark).

Quintana, X. D., Arim, M., Badosa, A., Blanco, J. M., Boix, D., Brucet, S., Compte, J., Egozcue, J. J., de Eyto, E., Gaedke, U., Gascón, S., Gil de Sola, L., Irvine, K., Jeppesen, E., Lauridsen, T. L., López-Flores, R., Mehner, T., Romo, S., \& Søndergaard, M.. (2015). Predation and competition effects on the size diversity of aquatic communities. Aquatic Sciences, 77(1), 45-57.

R Development Core Team (2019). R: A language and environment for statistical computing. R Foundation for Statistical Computing,Vienna, Austria. https://www.R-project.org/.

Radomski, R. J., Grant, G. C., Jacobson, P. C., \& Cook, M. R. (2001). Visions for recreational fishing regulations. Fisheries, 26,7-18.

Rahel, F. J. (2002). Homogenization of freshwater faunas. Annual review of ecology and systematics, 33(1), 291-315.

Regier, H. A., Whillans, T. H., Christie, W. J., \& Bocking, S. A. (1999). Over-fishing in the Great Lakes: The context and history of the controversy. Aquatic Ecosystem Health \& Management, 2(3), 239-248. 
Daupagne L., Rolan-Meynard M., Logez M. \& Argillier C. (2021). Effects of fish stocking and fishing pressure on fish community structures in French lakes. Fisheries Management and Ecology. 28(4),

317-327. DOI: 10.1111/fme.12476.

Rhymer, J.M., \& Simberloff, D.S. (1996). Extinction by hybridization and introgression. Annual Review of Ecology and Systematics, 27, 83-109.

Roques, S., Berrebi, P., Rochard, E., \& Acolas, M. L. (2018). Genetic monitoring for the successful re-stocking of a critically endangered diadromous fish with low diversity. Biological Conservation, 221, 91-102.

Rowe, D. K. (2004). Potential effects of tench (Tinca tinca) in New Zealand freshwater ecosystems. NIWA Client Report HAM2004-005.

Ruuhijärvi, J., Salminen, M., \& Nurmio, T. (1996). Releases of pikeperch (Stizostedion luciopera (L.)) fingerlings in lakes with no established pikeperch stock. Annales Zoologici Fennici, 33, 553-567.

Rypel, A. L., Lyons, J., Tober Griffin, J. D., \& Simonson, T. D. (2016). Seventy-year retrospective on size-structure changes in the recreational fisheries of Wisconsin. Fisheries, 41(5), 230-243.

Serns, S. L., \& Kempinger, J. J. (1981). Relationship of angler exploitation to the size, age, and sex of walleyes in Escanaba Lake, Wisconsin. Transactions of the American Fisheries Society, 110, 216-220.

Siberchicot, A., Julien-Laferrière, A., Dufour, A.-B., Thioulouse, J., \& Dray, S. (2017). adegraphics: an S4 lattice-based package for the representation of multivariate data. $R$ Journal, 9(2), 198-212.

Simon, K. S., \& Townsend, C. R. (2003). Impacts of freshwater invaders at different levels of ecological organisation, with emphasis on salmonids and ecosystem consequences. Freshwater biology, 48(6), 982-994.

Šmejkal, M., Ricard, D., Prchalová, M., Říha, M., Muška, M., Blabolil, P., Čech, M., Vašek, M., Jůza, T., Herreras, A. M., Encina, L., Peterka, J., Kubečka, J. (2015). Biomass and abundance biases in European standard gillnet sampling. PLOS ONE, 10(5), e0128469.

Snickars, M., Sundblad, G., Sandström, A., Ljunggren, L., Bergström, U., Johansson, G., \& Mattila, J. (2010). Habitat selectivity of substrate-spawning fish: modelling requirements for the Eurasian perch Perca fluviatilis. Marine Ecology Progress Series, 398, 235-243.

Snow, H. E. (1974). Effects of stocking northern pike in Murphy Flowage. Wisconsin Department of Natural Resources, Technical Bulletin 79.

Storfer, A./ (1999). Gene flow and endangered species translocations: a topic revisited. Biological Conservation, 87, 173-180.

Sullivan, M. G. (2003). Active management of walleye fisheries in Alberta: Dilemmas of managing recovering fisheries. North American Journal of Fisheries Management, 23(4), 1343-1358.

Suuronen, P., \& Bartley, D. M. (2014). Challenges in managing inland fisheries-using the ecosystem approach. Boreal Environment Research, 19(3), 245-255.

Sweeting, C. J., Badalamenti, F., D'Anna, G., Pipitone, C., \& Polunin, N. V. C. (2009). Steeper biomass spectra of demersal fish communities after trawler exclusion in Sicily. ICES Journal of Marine Science, 66(1), 195-202.

Tefera, D. A., Zerihun, M. M., \& Wolde-Meskel, Y. T. G. (2019). Catch distribution and size structure of Nile tilapia (Oreochromis niloticus) in Lake Tana, Ethiopia: Implications for fisheries management. African Journal of Aquatic Science, 44(3), 273-280.

Trenkel, V. M., \& Rochet, M.-J. (2003). Performance of indicators derived from abundance estimates for detecting the impact of fishing on a fish community. Canadian Journal of Fisheries and Aquatic Sciences, 60(1), 67-85.

Van Zyll de Jong, M., Gibson, R., \& Cowx, I. (2004). Impacts of stocking and introductions on freshwater fisheries of Newfoundland and Labrador, Canada. Fisheries Management and Ecology, 11(3-4), 183-193. 
Daupagne L., Rolan-Meynard M., Logez M. \& Argillier C. (2021). Effects of fish stocking and fishing pressure on fish community structures in French lakes. Fisheries Management and Ecology. 28(4),

317-327. DOI: 10.1111/fme.12476.

Vehanen, T. (1997). Fish and fisheries in large regulated peaking-power river reservoirs in northern Finland, with special reference to the efficiency of brown trout and rainbow trout stocking. Regulated Rivers: Research \& Management,13(1), 1-11.

Weithman, A. S. (1999). Socioeconomic benefits of fisheries. Inland fisheries management in North America, 2, 193-213.

Welcomme, R. L., Kohler, C. C., \& Courtenay Jr, W. R. (1983). Stock enhancement in the management of freshwater fisheries: A European perspective. North American Journal of Fisheries Management, 3(3), 265-275.

Welcomme, R. L. (1998). Evaluation of stocking and introduction as management tools. In I. G. Cowx (Ed.), Stocking and Introduction of Fish (pp. 397-413). Oxford: Fishing News Books, Blackwell Science.

Welcomme, R. L., \& Bartley, D. (1998). An evaluation of present techniques for the enhancement of fisheries. FAO Fisheries Technical Paper, 374, 1-36.

Welcomme, R. L. (1999). A review of a model for qualitative evaluation of exploitation levels in multi-species fisheries. Fisheries Management and Ecology, 6(1), 1-19.

Welcomme, R., \& Naeve, H. (2001). An international symposium on Fisheries and Society, Budapest, Hungary, 1-3 June 2000. Fisheries Management and Ecology, 8, 283-462.

Welcomme, R. L., Cowx, I. G., Coates, D., Béné, C., Funge-Smith, S., Halls, A., \& Lorenzen, K. (2010). Inland capture fisheries. Philosophical Transactions of the Royal Society B: Biological Sciences, 365(1554), 2881-2896.

Wilberg, M. J., Bence, J. R., Eggold, B. T., Makauskas, D., \& Clapp, D. F. (2005). Yellow perch dynamics in southwestern Lake Michigan during 1986-2002. North American Journal of Fisheries Management, 25(3), 1130-1152.

Winfield, I., \& Durie, N. (2004). Fish introductions and their management in the English Lake District. Fisheries Management and Ecology, 11(3-4), 195-201. 